\title{
VALUE ADDED TAX IN NEPAL: AN EMPIRICAL ASSESSMENT
}

\author{
R.K. Shah*
}

\begin{abstract}
In developing economies, resource gap is critical and widening resulting to huge fiscal and budgetary deficits. Therefore, revenue mobilization is challenging proposition in an economy like Nepal where majority of the people live in abject poverty. Tax administration lacks innovative mechanism to identify new taxpayers and bring them into tax-net. Tax reform agenda was the reform package and program of the government after the restoration of multiparty democracy system. In Nepal, VAT was introduced in 1997 to improve revenue mobilization through broadening the tax base and modernizing the tax system. In this process, the government had to face new problems that came along with the adoption of VAT. Thus, the purpose of this study is to analyze the structure and responsiveness of VAT in Nepal empirically and compare it with that of old system of sales taxes. The old system of sales taxes refers to the combined sales, entertainment, contracts, hotels, and air flight taxes received by the government before 1997/98.
\end{abstract}

\section{INTRODUCTION}

During the last two decades, Nepal had undergone various economic, social, and political changes. In this process, the government introduced a number of reform packages and programs. Tax reform agenda was one of such reform packages and programs of the government after the restoration of multi-party democracy system in 1990. The initial tax reform included two main components: first, the introduction of value added tax (VAT) and second, the enhancement of the capacity of the income tax administration (Nepal Law Society 2005).

In Nepal, VAT was introduced in 1997 to improve revenue mobilization through broadening the tax base and modernizing the tax system. In this process, the government had to face new problems that came along with the adoption of VAT. First, the benefits associated with switching from customs duty to VAT were yet to be realized in the presence of large informal and agricultural sector. Second, revenue loses around Rs. 600 million of customs duty following the liberal trade policy and drastic cuts in tariffs had to be compensated by increasing the voluntary registration of business firms on VAT. Finally, on the political front, the country was facing the period of intense turmoil due to political crisis, which sharply increased government's security expenses. This placed substantial pressure on the revenue front. In addition, even after a decade long reform exercise, revenue mobilization in Nepal was very low as compared to the expenditure requirement.

\footnotetext{
*Associate Professor, Mahendra Multiple Campus, Tribhuvan University, Nepalgunj, Nepal
} 
In this context, a sound knowledge of structure and responsiveness (i.e. its elasticity, buoyancy, rate structure, composition, growth rate, related issues, etc.) of major taxes has become essential 40 studies. Thus, the purpose of this study is to analyze the structure and responsiveness of VAT in Nepal empirically and compare it with that of old system of sales taxes. The old system of sales taxes refers to the combined sales, entertainment, contract, and air flight taxes received by the government before 1997/98.

\section{METHODOLOGY}

\section{THEORETICAL FRAMEWORK}

Buoyancy and elasticity are the two major concepts used in measuring the responsiveness of tax collection with respect to changes in GDP or national income. As an economy progressed, growth in taxes may come either through automatic growth (resulting from increase in tax base as the economy expands itself over time) or through discretionary tax changes (resulting from adjustment in tax rates, introduction of new taxes, and other tax policy changes of the government). Buoyancy coefficient (say $\beta_{1}$ ) reflects growth in taxes through both automatic growth as well as discretionary changes. i.e. it measures that total response of actual tax revenue (T) with respect to changes in GDP or national income (Y). Elasticity coefficient (say $\mathrm{B}_{2}$ ), on the other hand, involves the estimation of automatic growth in taxes at existing rates i.e. it measures the response of adjusted tax revenue $\left(\mathrm{T}_{\mathrm{a}}\right)$ with respect to changes in GDP or rational income (Y). Adjusted tax revenue refers to the net yield after eliminating the effects of discretionary tax change from actual tax receipts. It is a hypothetical revenue series (FNCCI 2006). Symbolically,

Buoyancy $\left(\beta_{1}\right)=(\Delta \mathrm{T} / \mathrm{T}) \mathrm{X}(\mathrm{Y} / \Delta \mathrm{Y})$

Elasticity $\left(\beta_{1}\right)=\left(\Delta / \mathrm{T}_{\mathrm{a}} / \mathrm{T}_{\mathrm{a}}\right) \mathrm{X}(\mathrm{Y} / \Delta \mathrm{Y})$

It is assumed that buoyancy coefficients are always greater than elasticity coefficients. The difference between these two coefficients reflect the response of taxes due to discretionary tax changes. It is argued that a good tax system should be equitable, efficient, administratively feasible, and elastic with higher automatic response, explained by the degree of progression and base expansion. If the tax system is elastic, it could ensure growth in taxes without the need for any politically difficult decisions through discretionary tax changes such as raising tax rates, introduction of new taxes, and other tax policy changes. On the other hand, it is also argued that discretionary tax changes are necessary for tapping new revenue sources as the government activities expand over time. However, reliance on such changes should be gradually decreased and focused on realizing findings through automatic growth in taxes at existing rates (Shakya 2005).

Elasticity of tax revenue could also be decomposed into parts: tax $\left(\mathrm{T}_{\mathrm{a}}\right)$ to base (B) and base (B) in income (Y) elasticity. Symbolically, (Mansfield, 1992):

$\beta_{3}=\Delta \mathrm{Ta} / \mathrm{TaX} \beta / \Delta \beta$ (tax to base elasticity)

$\beta_{4}=\Delta \beta / \beta \times Y / \Delta Y$ (base to income elasticity)

The product of equation (2.3) and (2.4) constituted elasticity of tax revenue $\left(B_{2}\right)$. Equation (2.3) shows the rate response, which reflects both 
progressiveness of rate structure and status of administration efficiency. In this context, (2.3) it is considered to be partly within the control of the authorities. On the other hand, equation (2.4) entails the base response, which lies outside the control of the authorities. It is determined by how the economy expands itself over time (Rao 1979).

\section{DATA DESCRIPTION}

The study covers the period of 18 years time series data starting from 1987/88 to 2004/05 (whole period), published by Ministry of Finance, Central Bureau of Statistics, and Inland Revenue Department of Nepal. Further, the whole period has been divided into two sub-periods viz, old sales taxes period (1987/88 to $1996 / 97)$ and VAT period (1997/98 to 2004/05).

\section{CONSTRUCTION OF AdJUSTEd REVENUE SERIES}

To estimate elasticity, first the adjusted revenue series should be constructed with the separation of effect of discretionary tax change from the normal growth. The study employs Sahota's Method for this purpose. The percentage contribution of new tax proposals to total estimated revenue has been taken in same proportion to calculate discretionary tax change from actual tax revenue by adopting following Sahota's Method (Khadka 1988):

$$
I T_{z}=\frac{A T_{z} \pm D T_{z}}{A T_{z-1}} \times I T_{z-1}
$$

Where, $\mathrm{IT}_{\mathrm{t}}$ refers to adjusted tax revenue at time $\mathrm{t}$; $\mathrm{It}_{\mathrm{t}-1}$ refers to adjusted tax revenue at time $(\mathrm{t}-1) ; \mathrm{AT}_{\mathrm{t}}$ refers to actual tax revenue at time $\mathrm{t} ; \mathrm{AT} \mathrm{t}-1$ refers to actual tax revenue at time $(\mathrm{t}-1) ; \mathrm{DT}_{1}$, refers to discretionary tax change at time $\mathrm{t}$.

\section{MODEL}

Assuming that the distribution of errors has an excepted value of zero and has finite variance, the regression equations specified to show the functional relationship between various variables are as follows:

Model for buoyancy $\left(\beta_{1}\right)$, elasticity $\left(\beta_{2}\right), \&$ tax to proxy base elasticity $\left(\beta_{3}\right)$ coefficients during the whole period (i.e. 1987/88 to 2004/05) [Rao 1979].

$$
\begin{aligned}
& \text { In } \mathrm{TR}_{\mathrm{t}}=\operatorname{In} \alpha+\beta_{1} \text { In } \mathrm{Y}_{\mathrm{t}}+\mu_{\mathrm{t}} \\
& \text { In TTR }=\text { In } \alpha+\beta_{1} \text { In } Y_{t}+\mu_{t} \\
& \text { In } \operatorname{VAT}^{\#}{ }_{\mathrm{t}}=\operatorname{In} \alpha+\beta_{1} \text { In } \mathrm{Y}_{\mathrm{t}}+\mu_{\mathrm{t}} \\
& \text { In } \mathrm{TRa}_{\mathrm{t}}=\operatorname{In} \alpha+\beta_{2} \text { In } \mathrm{Y}_{\mathrm{t}}+\mu_{\mathrm{t}} \\
& \text { In } \text { TTRa }_{\mathrm{t}}=\operatorname{In} \alpha+\beta_{2} \text { In } \mathrm{Y}_{\mathrm{t}}+\mu_{\mathrm{t}} \\
& \text { In VATa }{ }_{\mathrm{t}}^{\#}=\operatorname{In} \alpha+\beta_{2} \operatorname{In} \mathrm{Y}_{\mathrm{t}}+\mu_{\mathrm{t}} \\
& \text { In } \mathrm{VATa}_{\mathrm{t}}^{\#}=\operatorname{In} \alpha+\beta_{3} \text { In } \mathrm{YT}_{\mathrm{t}}+\mu_{\mathrm{t}}
\end{aligned}
$$

Model for buoyancy $\left[\beta_{4}\right.$ and $\left.\left(\beta_{4+} \beta_{5}\right)\right]$, elasticity $\left[\beta_{6}\right.$ and $\left.\left(\beta_{6+} \beta_{7}\right)\right]$, and tax to proxy base elasticity $\left[\beta_{8}\right.$ and $\left.\left(\beta_{8+} \beta_{9}\right)\right]$, coefficients during old sales taxes period (i.e. $1978 / 88$ to $1996 / 97$ ) and VAT period (i.e. $1997 / 98$ to $2004 / 05$ ).

$$
\begin{aligned}
& \operatorname{In~VAT~}_{t}^{\#}=\operatorname{In} \alpha_{1}+D_{t} \operatorname{In} \alpha_{2}+\beta_{4} \operatorname{In} Y_{t}+\beta_{5} D_{t}\left(\operatorname{In~} Y_{t}\right)+\mu_{t} \\
& \operatorname{In~VATa~}_{t}^{\#}=\operatorname{In} \alpha_{1}+D_{t} \operatorname{In} \alpha_{2}+\beta_{6} \operatorname{InY} Y_{t}+\beta_{7} D_{t}\left(\operatorname{In~} Y_{t}\right)+\mu_{t} \\
& \operatorname{In~VATa~}_{t}^{\#}=\operatorname{In} \alpha_{1}+D_{t} \operatorname{In} \alpha_{2}+\beta_{8} \operatorname{In} Y_{t}+\beta_{9} D_{t}\left(\operatorname{In~} Y_{t}\right)+\mu_{t}
\end{aligned}
$$


Note: Small letter 'a' refers to adjusted revenue series. All revenue and GDP series are in Rs. Million at correct price. VAT $^{\#}$ series includes contract, sales, hotel, entertainment, and air flight tax from 1987/88 to 1996/97 and includes VAT from $1997 / 98$ to $2004 / 05$. Y refers to GDP at factor cost before deducting bank service charge. YT refers to GDP from Trade, Restaurants, and Hotels. TR refers to Total Revenue. TTR refers to total tax revenue. D refers to dummy variable that takes values 1 (for observation in 1997/98 to 2004/05: VAT period) and O, otherwise (for observation in 1987/88 to 1996/97: old sales taxes period). For example: in equating (8): Mean VAT\# function for 1987/88 to 1996/97 E (In VAT ${ }^{\#} \mathrm{I}_{\mathrm{t}} \mathrm{D}_{\mathrm{t}}=\mathrm{O}$, In $\left.\mathrm{Y}_{\mathrm{t}}\right)=$ In $\alpha_{1}+\beta_{4}$ In $\mathrm{Y}_{\mathrm{t}}$; and Mean $\mathrm{VAT}^{\#}$ function for 1997/98 to 2004/05: E (In VAT ${ }^{\#} D_{t} D_{t}=I$, in $\left.Y_{t}\right)=\left(\operatorname{In} \alpha_{1}+\operatorname{In} \alpha_{2}\right)+\left(\beta_{4}+\beta_{5}\right)$ In $Y_{t}$.

\section{STRUCTURE AND RESPONSIVENESS OF VALUE ADDED TAX IN NEPAL}

\section{VALUE ADDED TAX IN NEPAL}

In Nepal, VAT was introduced on 16 November 1997 in place of sales, contract, entertainment, and hotel tax. It is the most modern form of indirect tax for Nepal. Value added by a firm is the difference between the receipts from the sales of the firm's product and the sum to the amounts paid by the firm for goods and services purchased during the period from other firms. VAT is shifted forward completely to the consumer (Dahal 2003).

There were mainly four reasons to introduce VAT in Nepal. First reason was to develop VAT as a main and stable source of government revenue by broadening the tax base. Second was to address the issue of smuggling or understate the taxable value, since the former sales tax was collected only at source and value added below this point was not included. Third was to reduce the dependence on customs duty since Nepal needed gradual reduction in imports tariff as its commitment to WTO, BIMSTEC, and SAFTA. Finally, it was argued to modernize the tax system by enhancing the accounting practice and transparency in business (Gujrati 2004).

VAT in Nepal, is legally bounded under Value Added Tax Act 1995 and Value Added Tax Rules 1997. These acts and rules were amended eight times including the recent amendments in 2005 under various successive Finance Ordinances. The basic features of VAT in Nepal are as follows (Due and Friedlaender 2002):

- VAT is levied at single rate of 13 percent (10 percent until 13 January 2005) and collected at every stage of production and distribution of goods and services. In certain cases, however, the rate may be zero or exempted.

- $\quad$ VAT is levied at the rate of zero percent on certain taxable goods and services such as exports, goods purchased or imported by accredited diplomats, etc.

- Certain products such as primary agricultural product, primary food stuffs, live animals and products, agricultural inputs, health services, education, books and newspaper, artistic/cultural goods and services, etc are exempted from VAT.

- A firm with annual turnover less than Rs. 2 million does not need to register with the VAT office but can register voluntarily. On the other 
hand, a firm whose annual turnover exceeding Rs. 1 million must issue a serially numbered invoice with firm's name, address and permanent account number.

- All firms conducting business in municipalities related to hardware, sanitation, furniture, fixture furnishing, electric, electronic and marbles must compulsorily registered with VAT Office.

\section{STATUES OF VAT COLLECTION}

For the first time, VAT became the largest source of revenue surpassing the customs duty by 0.6 percent of GDP in 2004/05, despite its negative growth in $1997 / 98$ and $2001 / 02$. There were mainly two reasons that led to the negative growth of VAT. First was the strong opposition by the business community against VAT during the initial period. Second was the political crisis and increased armed conflict between government security forces and Maoists that led the overall economic growth of the country negative. Even in such hostile political situation of the country, on an average, the government had somehow realized 3.1 percent of GDP as VAT (Tables 1 and 2).

Table 1. Status of VAT and Some selected Revenues

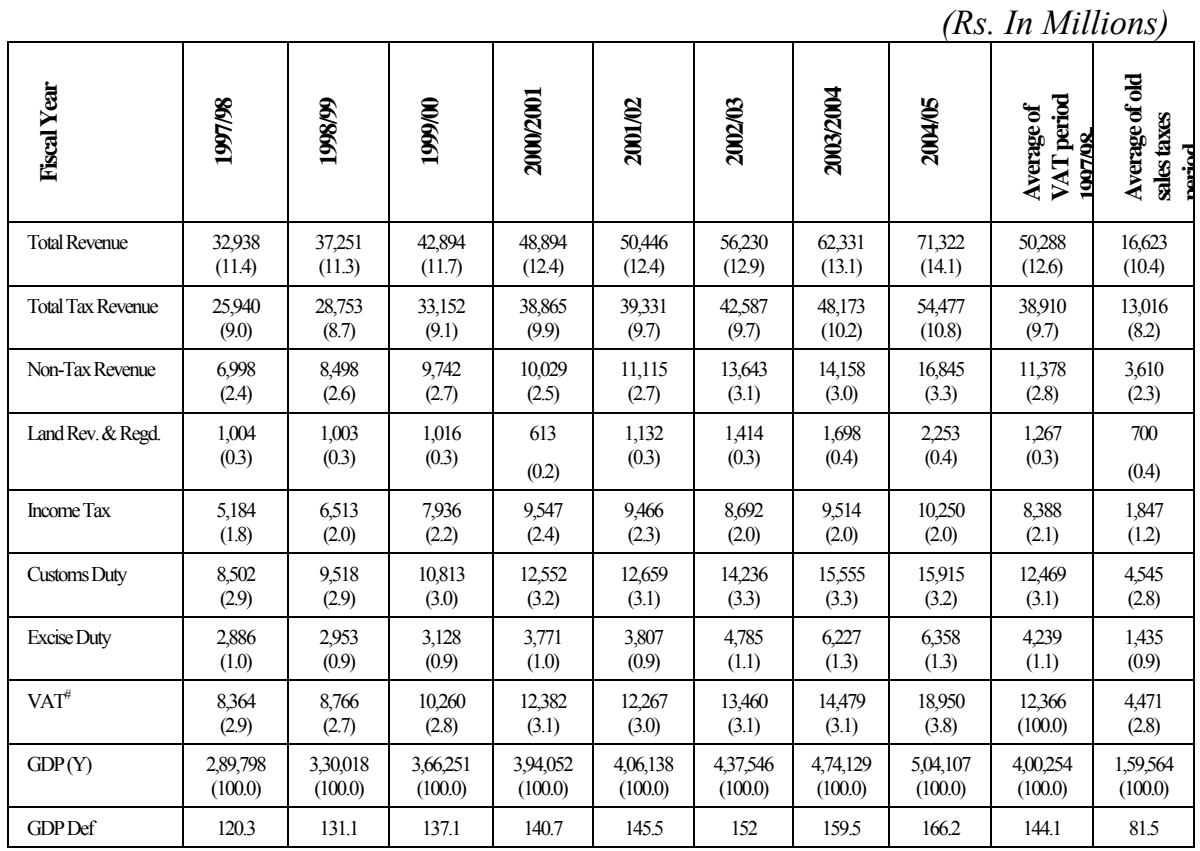

Source: Economic Survey 1998 and 2005, MoF; Budget Speech, Various Issues, MoF.

Note: Figures in parenthesis are percentage of GDP, All revenue and GDP series are at current price; GDP Deflator 1994/95 = 100 . 
Table 2. Growth Rate of VAT

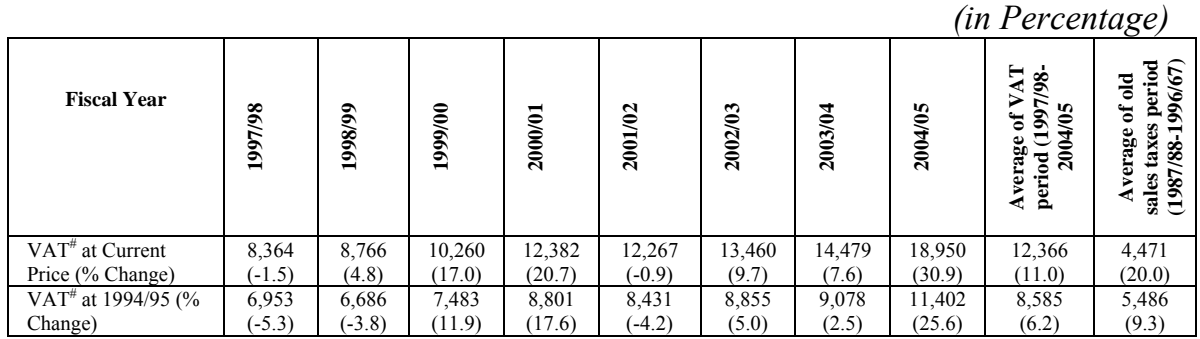

Source: Economic Survey 1998 \& 2005, MoF; Budget Speech, Various Issues, MoF.

Further, on an average, the government realized increased revenue from all sources (including VAT) during VAT period as compared to old sales taxes period (Table 1). The government would have realized even more revenue through VAT if it was implemented with proper taxpayer's education and co-operation of business communities. In fact, business immunities still do not digest VAT and their cooperations are limited. In addition, given the long list of exempted items and higher threshold, it is obvious that its current collection is far below the actual potentiality.

\section{COMPOSITION OF VAT}

VAT is collected under various headings; such as VAT on production, imports, sales/distribution, contract/consultancy, tourism industries, and other services. On an average, VAT on imports (61.4 percent) constituted a largest share in total VAT collection. That is, significant amount of VAT was still collected at customs. In this sense, VAT collection also hinges upon the capacity of customs department especially related to dealing with issues like smuggling, under-invoicing, and massive amount of informal and unauthorized imports that takes place at various custom points (Table 3).

Table 3. Composition of VAT

\begin{tabular}{|c|c|c|c|c|c|c|c|}
\hline FY & Production & Imports & $\begin{array}{c}\text { Sales/ } \\
\text { Dist. }\end{array}$ & $\begin{array}{c}\text { Contract/ } \\
\text { Consult }\end{array}$ & $\begin{array}{c}\text { Tourism } \\
\text { Indus. }\end{array}$ & $\begin{array}{c}\text { Other } \\
\text { Services }\end{array}$ & $\begin{array}{c}\text { Total } \\
\text { VAT }\end{array}$ \\
\hline $1997 / 98$ & $1,165.1$ & $5,021.7$ & 125.5 & 761.6 & 389.3 & 901.0 & $8,364.2$ \\
& $(13.9)$ & $(60.0)$ & $(1.5)$ & $(9.1)$ & $(4.7)$ & $(10.8)$ & $(100.0)$ \\
\hline $1998 / 99$ & $1,305.2$ & $5,069.5$ & 441.8 & 618.0 & 242.2 & $1,089.3$ & $8,766.0$ \\
& $(14.9)$ & $(57.8)$ & $(5.0)$ & $(7.0)$ & $(2.8)$ & $(12.4)$ & $(100.0)$ \\
\hline $1999 / 00$ & $1,341.1$ & $6,129.2$ & 822.0 & 374.5 & 1.8 & $1,591.0$ & $10,259.6$ \\
& $(13.1)$ & $(57.8)$ & $(8.0)$ & $(3.7)$ & $(0.0)$ & $(15.5)$ & $(100.0)$ \\
\hline $2000 / 01$ & $1,755.4$ & $7,303.0$ & 920.6 & 510.8 & 0.3 & $1,892.3$ & $12,382.4$ \\
& $(14.2)$ & $(59.0)$ & $(7.4)$ & $(4.1)$ & $(0.0)$ & $(15.3)$ & $(100.0)$ \\
\hline $2001 / 02$ & $1,711.1$ & $7,354.9$ & 823.4 & $2,375.8$ & 0.0 & 2.1 & $12,167.3$ \\
& $(13.9)$ & $(60.0)$ & $(7.4)$ & $(19.4)$ & $(0.0)$ & $(0.0)$ & $(100.0)$ \\
\hline $2002 / 03$ & $1,896.7$ & $8,628.6$ & 676.3 & 757.9 & 251.4 & $1,248.8$ & $12,459.7$ \\
& $(14.1)$ & $(64.1)$ & $(5.0)$ & $(5.6)$ & $(1.9)$ & $(9.3)$ & $(100.0)$ \\
\hline $2003 / 04$ & $1,957.1$ & $8,874.8$ & 839.5 & 850.6 & 336.3 & $1,620.6$ & $14,478.9$ \\
& $(13.5)$ & $(61.3)$ & $(5.8)$ & $(5.9)$ & $(2.3)$ & $(11.2)$ & $(100.0)$ \\
\hline $2004 / 05$ & $2,188.5$ & $12,385.0$ & $1,125$. & $1,050.0$ & 351.5 & $1,850.0$ & $18,950.0$ \\
& $(11.5)$ & $(65.4)$ & $0(5.9)$ & $(5.5)$ & $(1.9)$ & $(9.8)$ & $(100.0)$ \\
\hline Average & $1,665.0$ & $7,595.8$ & 721.8 & 912.4 & 196.6 & $1,274.4$ & $12,366.0$ \\
& $(13.5)$ & $(61.4)$ & $(5.8)$ & $(7.4)$ & $(1.6)$ & $(10.3)$ & $(100.0)$ \\
\hline
\end{tabular}

Source: Economic Survey 1998 and 2005, MoF; Budget Speech, Various Issues, MoF.

Note: Figures in brackets are the percentage of Total VAT collection; All revenues are at current price. 


\section{VAT ADMINISTRATION}

Initially, there were 17 offices under department of VAT and 40 offices under department of Income tax (Khadka 2000). In 2001/02, both departments were merged into a single department (called Inland Revenue Department) to establish single, efficient, and independent revenue authority. Presently, there are 22 offices under Inland Revenue Department. Within these offices, there is one large taxpayer office, which was established in July 2004 to serve large taxpayers. Although the number of large taxpayers were very small, this sort of special treatment was felt necessary because of their large contribution in total revenue collection. Their contribution constituted nearly two third of total revenue to the total revenue collection. Their contribution constituted nearly two third of total revenue to the government (IRD 2006). At the end of old sales taxes period, the total number of sales tax registrants was only 2,045 while the number of VAT registrants increased to 44,553 and still increasing day by day (Table 4).

During the VAT period, average annual growth rate of compulsory and country registrants of VAT was 29.2 and 88.5 percent respectively. Similarly, average annual growth rate of total registration was 37.2 percent. The growth of voluntary registrants was higher than that of compulsory registrants (Table 4). In fact, registration of VAT surpassed the tenth plan target of 40,000. However, there are still many prospective registrants, which can be brought into VAT net. Further, the government was completely unable to improve billing enforcement, monitoring, develop accounting habit of the taxpayers, and avoid tax evasion. Even programs like bill based lottery system introduced to encourage consumers to take bill during their purchase was not that productive, it was noticed that sellers did not want to issue bill, hiding their transaction stand minimize tax. Similarly, buyers did not even bother to take bills. Similarly, exchanges of allegations were common between business community and tax officials accusing each other of being dishonest and corrupt (Khadka 2005).

Table 4. Compulsory, Voluntary, and Total Registrants of VAT

\begin{tabular}{|c|c|c|c|c|c|c|}
\hline $\begin{array}{c}\text { Fiscal } \\
\text { Year }\end{array}$ & $\begin{array}{c}\text { Compulsory } \\
\text { (CR) }\end{array}$ & $\begin{array}{c}\text { Voluntary } \\
\text { (VR) }\end{array}$ & $\begin{array}{c}\text { Total } \\
\text { (TREG) }\end{array}$ & CR & VR & TREG \\
\hline \multicolumn{7}{|c|}{} \\
\hline $1997 / 98$ & 4,664 & 538 & 5,247 & - & - & (\% Change) \\
\hline $1998 / 99$ & $6,7.1$ & 2,986 & 9,687 & 43.7 & 412.2 & 84.6 \\
\hline $1999 / 00$ & 12,455 & 5,736 & 18,191 & 85.9 & 92.1 & 87.8 \\
\hline $2000 / 01$ & 16,442 & 6,322 & 2,764 & 32.0 & 10.0 & 25.1 \\
\hline $2001 / 02$ & 18,896 & 8,458 & 27,354 & 14.9 & 33.8 & 20.2 \\
\hline $2002 / 03$ & 20,921 & 10,147 & 31,068 & 10.7 & 20.0 & 13.6 \\
\hline $2003 / 04$ & 22,801 & 12,975 & 35,776 & 9.0 & 27.9 & 15.2 \\
\hline $2004 / 05$ & 24,693 & 16,018 & 40,711 & 8.3 & 23.5 & 13.8 \\
\hline $2005 / 06$ & - & - & 44,553 & & - & 9.4 \\
\hline \multicolumn{7}{|c|}{ Average Excluding 2005/06... } \\
\hline
\end{tabular}

Source: RAS Project (2005), Inland Revenue Department, Nepal.

Note: @ figures until 10 April 2006

\section{RESPONSIVENESS OF VAT}

The measures of responsiveness of VAT as per the methodology mentioned above were statistically significant (except regression equation No. 8). 
However, the responsiveness of VAT and the whole tax system was rather disappointing and frustrating. On an average, the buoyancy and elasticity coefficient of $\mathrm{VAT}^{\#}$ to GDP was 1.236 and 0.616 respectively during the whole period, indicating that 1 percent increase in GDP was accompanied by only 0.616 percent increase in $\mathrm{VAT}^{\#}$ due to automatic growth and 0.620 percent (1.2360.616 ) increase due to discretionary tax changes. Similarly, on an average, the buoyancy and elasticity coefficient of total revenue to GDP was 1.193 and 0.585 respectively during the same period. On the other hand, the buoyancy and elasticity coefficient of total tax revenue to GDP was 1.178 and 0.537 respectively. This indicated that the $\mathrm{VAT}^{\#}$ and the whole tax system lacked automatic response, since their elasticities were less than unity (Table 6)

\begin{tabular}{|c|c|c|c|c|c|c|c|}
\hline $\begin{array}{c}\text { Equation } \\
\text { No. }\end{array}$ & \multicolumn{3}{|c|}{ Buoyancy Result } & $\mathbf{r}^{2}$ & $-r^{2}$ & $\mathbf{F}_{(1,16)}$ & $\begin{array}{c}d(n=18 ; \\
k^{\prime}=1\end{array}$ \\
\hline 1 & $\begin{array}{c}\wedge \\
\left(\operatorname{InTR}_{\mathrm{t}}\right)=\end{array}$ & $\begin{array}{c}-4.730 \\
(-15.367) \\
\end{array}$ & $\begin{array}{c}+1.205 \mathrm{InY}_{\mathrm{t}} \\
(48.335)\end{array}$ & 0.996 & 0.993 & $2,336.3$ & 0.863 \\
\hline 2 & $\hat{\left(\operatorname{InTR}_{\mathrm{t}}\right)}=$ & $\begin{array}{c}-4.922 \\
(-13.612)\end{array}$ & $\begin{array}{c}+1.200 \operatorname{InY}_{\mathrm{t}} \\
(40.980)\end{array}$ & 0.991 & 0.990 & $1,679.4$ & 0.768 \\
\hline 3 & $\left.\hat{(n V A T}_{t}^{\#}\right)=$ & $\begin{array}{c}-6.501 \\
(-12.868) \\
\end{array}$ & $\begin{array}{c}-1.236 \mathrm{InY} Y_{\mathrm{t}} \\
(30.222)\end{array}$ & 0.983 & 0.982 & 913.4 & 0.800 \\
\hline \multicolumn{8}{|c|}{ Elasticity Result } \\
\hline 4 & $\begin{array}{c}\wedge \\
(\text { InTRat })=\end{array}$ & $\begin{array}{c}2.207 \\
(5.144) \\
\end{array}$ & $\begin{array}{c}-0.597 \operatorname{InY} Y_{t} \\
(17.187)\end{array}$ & 0.949 & 0.945 & 295.4 & 0.478 \\
\hline 5 & $\begin{array}{c}\wedge \\
(\text { InTTRat })=\end{array}$ & $\begin{array}{c}2.363 \\
(4.860) \\
\end{array}$ & $\begin{array}{c}+0.560 \mathrm{InY}_{\mathrm{t}} \\
(14.213)\end{array}$ & 0.927 & 0.922 & 202.0 & 0.457 \\
\hline 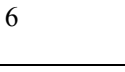 & $\left.\begin{array}{c}\wedge \\
(\operatorname{InVATa} \\
t\end{array}\right)=$ & $\begin{array}{c}1.880 \\
(1.638) \\
\end{array}$ & $\begin{array}{c}+0512 \mathrm{In} \mathrm{Y}_{\mathrm{t}} \\
(5.513)\end{array}$ & 0.655 & 0.634 & 30.4 & 0.244 \\
\hline \multicolumn{8}{|c|}{ Tax to Base Elasticity Result } \\
\hline 7 & $\begin{array}{c}\wedge \\
\left(\operatorname{InVATa}_{t}^{\#}\right)=\end{array}$ & $\begin{array}{c}2.706 \\
(3.075) \\
\end{array}$ & $\begin{array}{c}+0.542 \operatorname{InY} \mathrm{T}_{\mathrm{t}} \\
(6.254)\end{array}$ & 0.710 & 0.692 & 36.1 & 0.290 \\
\hline
\end{tabular}

Table 6 Empirical Results of Buoyancy $\left(\beta_{1}\right)$, Elasticity $\left(\beta_{2}\right)$, and Tax to Base Elasticity $\left(\beta_{3}\right)$

Coefficients During the Whole Period (1987/88 to 2004/05) After Removing Autocorrelation by Prais-Winsten Method.

\begin{tabular}{|c|c|c|c|c|c|c|c|}
\hline $\begin{array}{c}\text { Equation } \\
\text { No. }\end{array}$ & \multicolumn{3}{|c|}{ Buoyancy Result } & $\mathbf{r}^{2}$ & $-r^{2}$ & $F_{(1,16)}$ & $\begin{array}{c}d(n=18 ; \\
k^{\prime}=1\end{array}$ \\
\hline 1 & $\begin{array}{c}\wedge \\
\left(\operatorname{InTR}_{t}\right)=\end{array}$ & $\begin{array}{c}-4.576 \\
(-10.543)^{*}\end{array}$ & $\begin{array}{c}+1.193 \mathrm{In} \mathrm{Y} \mathrm{t}_{\mathrm{t}} \\
(33.910)^{*}\end{array}$ & 0.987 & 0.985 & $1,152.0$ & 1.366 \\
\hline 2 & $\begin{array}{c}\hat{\wedge} \\
\left(\operatorname{InTT}_{t}\right)=\end{array}$ & $\begin{array}{c}-4.644 \\
(-8.170)^{*}\end{array}$ & $\begin{array}{c}+1.178 \operatorname{InY} Y_{t} \\
(25.568)^{*}\end{array}$ & 0.978 & 0.975 & 657.2 & 1.253 \\
\hline 3 & $\begin{array}{c}\wedge \\
\left(\operatorname{InVAT}{ }_{t}\right)=\end{array}$ & $\begin{array}{c}-6.480 \\
(-8.170)^{*}\end{array}$ & $\begin{array}{c}+1.236 \mathrm{InY} Y_{t} \\
(19.203)^{*}\end{array}$ & 0.961 & 0.956 & 369.3 & 1.287 \\
\hline \multicolumn{8}{|c|}{ Elasticity Result } \\
\hline 4 & $\begin{array}{c}\wedge \\
(\operatorname{InTRat})=\end{array}$ & $\begin{array}{c}2.352 \\
(3.085)^{*}\end{array}$ & $\begin{array}{c}+0.585 \text { In } Y_{t} \\
(9.449)^{*}\end{array}$ & 0.856 & 0.837 & 89.7 & 1.576 \\
\hline 5 & $\begin{array}{c}\wedge \\
(\text { InTTRat })=\end{array}$ & $\begin{array}{c}2.633 \\
(3.013)^{*}\end{array}$ & $\begin{array}{c}+0.537 \text { In } Y_{t} \\
(7.572)^{*}\end{array}$ & 0.793 & 0.765 & 57.7 & 1.265 \\
\hline 6 & $\begin{array}{c}\wedge \\
\left(\operatorname{InVATa}{ }_{t}^{\#}\right)=\end{array}$ & $\begin{array}{c}0.559 \\
(0.274) \\
\end{array}$ & $\begin{array}{c}+0.616 \text { In } \mathrm{Y}_{\mathrm{t}} \\
(3.719)^{*}\end{array}$ & 0.480 & 0.410 & 13.9 & 0.739 \\
\hline \multicolumn{8}{|c|}{ Tax to Base Elasticity Result } \\
\hline 7 & $\left.\begin{array}{c}\wedge \\
\left(\operatorname{InVATa}{ }_{t}\right. \\
t\end{array}\right)=$ & $\begin{array}{l}2.032 \\
(1.320)\end{array}$ & $\begin{array}{l}+0.606 \mathrm{InYT}_{\mathrm{t}} \\
(3.972)^{*}\end{array}$ & 0.513 & 0.448 & 15.8 & 0.843 \\
\hline
\end{tabular}

Note: *Significant at 1 percent; Figures in brackets are t values. 
Since larger portion of VAT and old sales taxes were collected from the trade sector, GDP from trade, restaurants, and hotels was taken as a proxy base and regressed with $\mathrm{VAT}^{\#}$ and old sales taxes. The result disclosed that tax to proxy base elasticity of $\mathrm{VAT}^{\#}$ was also very low (0.616), indicating lack of efficient tax administration and progressive taxation (Table 6).

Table 7. Empirical Results of Buoyancy $\left[\beta_{4}\right.$, and $\left.\left(\beta_{4+} \beta_{5}\right)\right]$, Elasticity $\left[\beta_{6}\right.$, and $\left.\left(\beta_{6+} \beta_{7}\right)\right]$, Tax Base Elasticity $\left[\beta_{8}\right.$, and $\left.\left(\beta_{8}+\beta_{9}\right)\right]$, Coefficients During Old Sales taxes Period (1987/88 to 1996/97) and VAT Period (1997/88 to 2004/25)

\begin{tabular}{|c|c|c|c|c|c|c|c|c|c|}
\hline $\mathbf{E q}^{\mathbf{n}}$ & \multicolumn{5}{|c|}{ Buoyancy Results of VAT and Old Sales Period } & $\mathbf{R}^{2}$ & $-\mathbf{R}_{2}$ & $\mathbf{F}_{(13,14)}$ & $d\left(_{n=18 ; k^{\prime}}\right.$ \\
\hline 8 & $\begin{array}{c}\wedge \\
\left(\operatorname{InVAT}_{\mathrm{t}}^{\#}\right)=\end{array}$ & $\begin{array}{l}-8.272 \\
(-11.080)^{*}\end{array}$ & $\begin{array}{l}-0.642 \mathrm{D}_{\mathrm{t}} \\
(-0.274)\end{array}$ & $\begin{array}{l}+1.388 \\
\operatorname{InY}_{\mathrm{t}} \\
(22.128)^{*}\end{array}$ & $\begin{array}{l}+0.033 \\
(\mathrm{Dt} \mathrm{nYT}) \\
(0.177)\end{array}$ & 0.990 & 0.988 & 464.3 & 1.466 \\
\hline \multicolumn{10}{|c|}{ Elasticity Results of VAT and Old Sales Period } \\
\hline 9 & $\begin{array}{c}\wedge \\
\left(\operatorname{InVATa}_{t}^{\#}\right)=\end{array}$ & $\begin{array}{l}-4.491 * \\
(-5.159)^{*}\end{array}$ & $\begin{array}{l}+11.809 \mathrm{D} \\
\mathrm{t}(4.319)^{*}\end{array}$ & $\begin{array}{l}+1.055 \\
\operatorname{InY}_{\mathrm{t}} \\
(14.428)^{*}\end{array}$ & $\begin{array}{l}-0.974 \\
\left(D_{t} \operatorname{In} Y_{t}\right. \\
(-4.550)^{*}\end{array}$ & 0.947 & 0.936 & 84.2 & 1.706 \\
\hline \multicolumn{10}{|c|}{ Tax To Base Elasticity Results of VAT and Old Sales Tax Period } \\
\hline 10 & $\begin{array}{c}\wedge \\
\left(\operatorname{InVATa}_{t}^{\#}\right)=\end{array}$ & $\begin{array}{l}-1.536 \\
(-2.470)^{* *}\end{array}$ & $\begin{array}{l}+9.244 \mathrm{D}_{\mathrm{t}} \\
(3.062)\end{array}$ & $\begin{array}{l}+0.988 \\
\operatorname{InYT}_{\mathrm{t}} \\
(15.445)^{*}\end{array}$ & $\begin{array}{l}0.926 \\
\left(\mathrm{D}_{\mathrm{t}} \operatorname{InYT}_{\mathrm{t}}\right) \\
(-3.257)^{*}\end{array}$ & 0.954 & 0.944 & 96.2 & 1.593 \\
\hline
\end{tabular}

Note: Significant at 1 percent;** Significant at 5 percent; Figures in brackets are $\mathrm{t}$ values.

In comparing the response of VAT and old sales taxes, the result disclosed that the performance of VAT was very poor. On an average, the buoyancy and elasticity coefficient of old sales taxes to GDP was 1.388 and 1.055 respectively. Conversely, the buoyancy coefficient of VAT to GDP had not increased at all, since the t value of $\left(\beta_{4}+\beta_{5}\right)$ was statistically insignificant. On the other hand, the elasticity of VAT to GDP had substantially decreased to 0.081 . Finally, the tax to proxy base elasticity of VAT was also very low (0.062) as compared to that of old sales taxes (0.988), indicating that 1 percent increase in proxy base was accompanied by only 0.062 percent increase in VAT against 0.988 percent of old sales taxes, without any discretionary tax change (Table 7). 
From the above analysis, it can be concluded that discretionary tax changed had largely influenced the current collection of VAT. VAT significantly lacked automatic growth as compared to old sales taxes and it was the discretionary tax changes, mainly through increasing tax rates and the other hand, it was also noticed that VAT lacked administrative efficiency and progressive taxation that had resulted in a very low to proxy base elasticity of VAT as compared to that of old sales taxes.

\section{CONCLUSION}

To conclude, I argue that despite the realization of increased revenue from all sources including VAT, the tax effort is still poor in Nepal. The favorable increase in VAT and the whole tax system cannot be considered because of their automatic response capacity resulting from increase in tax base. Rather, it is the outcome of significant discretionary tax changes like increasing tax rates, introducing new taxes, and other tax policy changes. This has led to much higher buoyancy as compared to their respective elasticity of VAT and the whole tax system. Further, VAT is significantly lacking administrative efficiency, in terms of, billing enforcement, mortaring, commitment, and progressive taxation that resulted in very low tax to base elasticity of VAT. In fact, these are not only the reasons behind the few achievements of VAT. Rather, it is also associated with the economic stagnation and slow growth in tax base, increased violence, traditional type of customs administration, and low level of tax consciousness among taxpayers, lack of stable tax policy, and the whole structure of tax administration of the country. Therefore, there is a need for immediate action by the government in developing and implementing the following reform measures:

- $\quad$ Initiate effective programs to enhance taxpayer education by increasing participation of business communities.

- Improve billing enforcement, monitoring, and encourage taxpayers to maintain good accounting habit.

- $\quad$ Bring reliable and strict policies in customs to deal with issues like smuggling, under-invoicing, and massive amount of informal and unauthorized imports that take place at various custom points to avoid leakage in VAT. Similarly, establish proper network within customs and inland Revenue Department.

- $\quad$ Bring more untapped source into VAT net.

- $\quad$ Bring as many taxpayers as possible into VAT net.

- $\quad$ Reduce threshold and exempted items to avoid erosion in tax base.

- $\quad$ Encourage bill based lottery system through effective advertisement and 
bring more other programs to improve billing enforcement.

- Bring reliable and strict rules and regulation in VAT. Similarly, encourage hones taxpayers through good services and penalize those who break rules.

- $\quad$ Finally, adopt a stable long-term policy on VAT, focusing on broadening the tax base rather than increasing tax rate.

\section{WORKS CITED}

Charles Y. Mansfield. 1972. Elasticity and Buoyancy of a Tax System: A Method Applied to Paraguay. IMF Staff Papers 19(2):42.

Dahal, M. K, 2000. Measuring the Responsiveness and Productivity of Tax Yields: A Survey of the Contemporary Approach. The Economic Journal of Development Issue 1(2): 35.

Due, John F. and A.F. Friedlander. 2000. Government Finance: Economics of the Public Sector. A.I.T.B.S Publishers and Distributors, New Delhi. Pages 104.

Federation of Nepalese Chamber of Commerce and Industries. 2006 Finance Ordinance to Improve Transparency. Byabasaik Aacharan Newsletter 2(4): 88.

Gujarati, N. 2004. Basic Econometrics. Fourth edition, Tata McGraw-Hill, New Delhi. Pages 204.

Inland Revenue Department. 2006. VAT ACT. www.ird.gov.np (Website of Inland Revenue Department.

Khadka, R. 2000. The Nepalese Tax System. Shajha Prakashan, Kathmandu. Pages 98.

2005. Modernizing Tax Administration in Nepal. Pairavi Prakashan, Kathmandu. Pages 54.

2001. VAT in Nepal. USB Publishers' and Distributors Ltd., New Delhi. Pages 99.

1988. The Responsiveness of the Nepalese Tax System, Rajaswa, AprilMay. Pages 104.

Mansfield, Y. 2002. Taxation in India, Allied Publishers Pvt. Ltd., New Delhi, pages 66. 
Nepal Law Society. 2005. Impact Assessment Study on Danish Support to Revenue Reform. A Report Submitted to DANIDA-RAS Project, Kathmandu. Pages 76.

Rao, V.G. 2003. Elasticity and Buoyancy of Taxation. Deep and Deep Publications, New Delhi. Pages 207.

Shakya, J. 2005. Structure and Responsiveness of Nepalese Tax System. Unpublished M.A. Thesis, T.U., Kathmandu.

Singh, S.K. 1997. Indian Tax System: 1960-61 to 1973-74. Allied Publishers Pvt. Ltd., New Delhi. Pages 8-94. 